\title{
Design, Installation and Commissioning Of Clean Room and Hvac Facility for Stem Cell Technologies and Regenerative Medicine
}

\author{
Y.Venkata Bharath, P.Lakshmi Reddy \\ 1 ( Mechanical Engineerig, G.Pulla Reddy Engineerig College (Autonomous) /J Ntu Anantapur , India) \\ 2 (Mechanical Engineerig, G.Pulla Reddy Engineerig College (Autonomous) /J Ntu Anantapur, India)
}

\begin{abstract}
Today, many manufacturing process requires that spaces to be designed to control particulate and microbial contamination while maintaining clean room facility with reasonable installation and operating costs. Clean room facilities are typically used in manufacturing, packaging and research facilities associated with these industries: Semiconductor, Pharmaceutical, Hospitals, Aerospace and Miscellaneous applications. This project deals with "Design, Installation and Commissioning of Clean room and HVAC facility for Stem cell technologies and Regenerative Medicine". In this thesis, the system design thermal loads , filtration level and cleanness, pressures produced in the constructed building by varying normal brick wall, brick wall with attached panels are calculated.Clean rooms are designed as per ISO14644-4 guidelines to maintain proper air flow in order to used proper cleanness. The HVAC facility shall be achieved by using the equipments like Air cooled condensing unit, Air handling units and etc..As a First step towards the project, the system design load calculations will be done. Air Quantity calculation, Supply/Return air Diffusers, Return Air Risers and Terminal filters selection, Temperature, RH, Lighting and Fan requirements are as per attached design data sheets. The classes of cleanliness, filtration and other requirements are to be as per the room list, layout drawings. The minimum fresh air quantities shall be as per the basis of design above while the exhaust air quantities shall be as based on the quantities of the leakages and pressures to be maintained in the rooms and Also the leakage rates considered through the doors to be through the doors to be through a normal single leaf door or double leaf door for the suggested pressure differentials to be suitably considered.
\end{abstract}

Keywords: Clean rooms, HVAC facility, Filters, Pressures, Panels ,Temperature, Air flow rates.

\section{Introduction}

A Clean Room is a controlled environment where products are manufactured. It is a room in which the concentration of airborne particles is controlled to specified limits. Eliminating sub-micron airborne contamination is really a process of control. These contaminants are generated by people, process, facilities and equipment. They must be continually removed from the air. The level to which these particles need to be removed depends upon the standards required.

The HVAC facility necessity for atmospheric conditions in India is varying in different places of the country. In the summer season atmospheric conditions are quite un comfortable in most parts of the country and winter conditions are uncomfortable in few places of the country. So air conditioning is essential for the comfort of humans, equipment and facilities are staying in hospital. In this thesis, the system design thermal loads, filtration level and cleanness, pressures produced in the constructed building by varying normal brick wall ,brick wall with attached panels are calculated.

The main purpose of clean room and hvac facilities are to supply sufficient amount of air, which should maintain correct temperature, humidity, air purity, air movement and noise level. Occupant's feels quite comfort in a selected enclosure by maintaining all the factors correctly. The high capacity requirements suggest the selection of air handling units and require high efficiency filters.

This project work has been intended to suggest a suitable clean room facility and comfort air conditioning design for the various public areas and rooms of a proposed Nims hospital at Hyderabad. In this hospital $6^{\text {th }}$ floor contains 12 - Clean rooms which have to be cleaned and conditioned and 7-Air lock rooms, 8Nurse observation rooms, 2-Corridors, 14-Other rooms, 8- Wash rooms which have to be conditioned.

The centralized air conditioning system is suggested for that hospital considering summer and winter conditions at Hyderabad.

\section{Cleanroom Facility}

Clean rooms are defined as specially constructed, environmentally controlled enclosed spaces with respect to airborne particulates, temperature, humidity, air pressure, airflow patterns, air motion, vibration, noise, viable (living) organisms, and lighting. Particulate control includes: 
$>$ Particulate and microbial contamination

$>$ Particulate concentration and dispersion

"Federal Standard 209E" defines a clean room as a room in which the concentration of airborne particles is controlled to specified limits.

"British Standard 5295" defines a clean room as a room with control of particulate contamination, constructed and used in such a way as to minimize the introduction, generation and retention of particles inside the room and in which the temperature, humidity, airflow patterns, air motion and pressure are controlled.

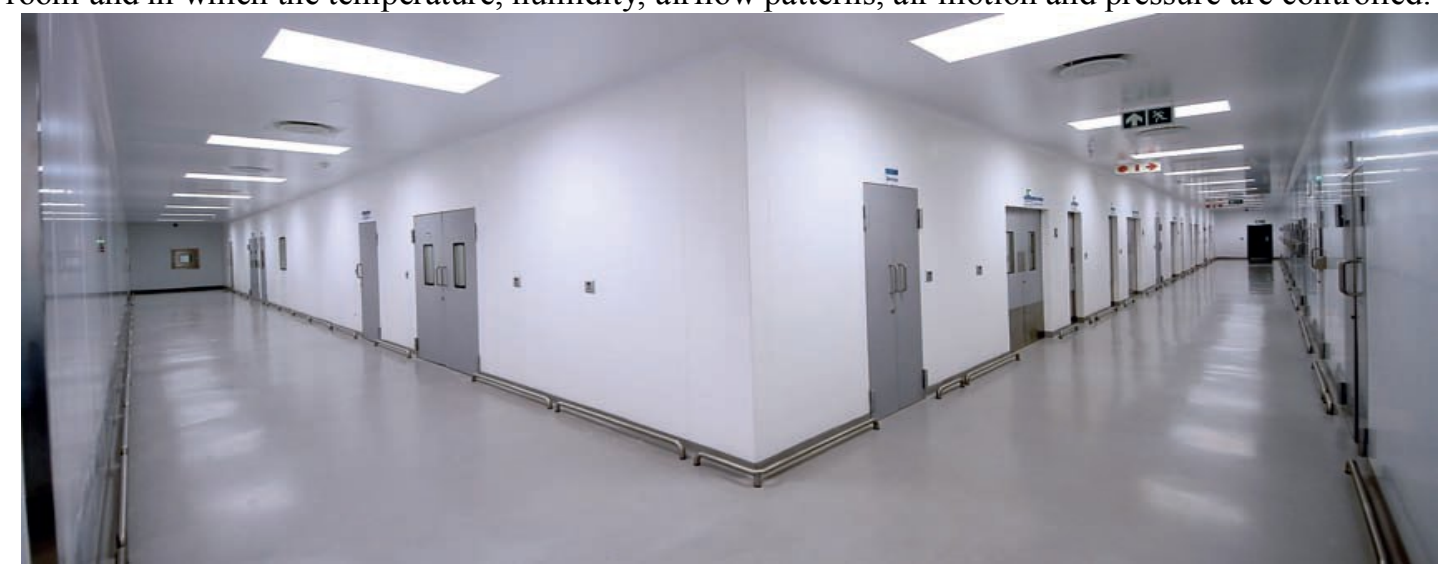

\subsection{Clean Room Classification:}

The industry differentiates between the cleanliness of rooms by referring to class numbers. Federal Standard 209E, "Airborne Particulate Cleanliness Classes in Clean Rooms and Clean Zones", September 11, 1992, categorize clean rooms in six general classes, depending on the particle count (particles per cubic foot) and size in microns $\left(k_{\mathrm{m}}\right)$. The first three classes allow noparticles exceeding 0.5 microns $(\mathrm{m})$, and the last three allowing some particles up to 5.0 microns. Interpreting the table above, a class 100,000 clean room limits the concentration of airborne particles equal to or greater than 0.5 microns to 100,000 particles in a cubic foot of air.

ISO/TC209 clean room class ratings are slowly replacing the Federal Standard 209E ratings. ISO/TC209 is based on metric measurements whereas Federal Standard 209E that is based on imperial measurements. The classes, according to ISO/TC209 14644-1, are in terms of class levels 3, 4, 5...of airborne particulate cleanliness. A Class 5 means that less than 3,520 particles ( 0.5 microns in size $)$ are present per cubic meter, which equals 100 particles per cubic foot. A Class 6 indicates less than 35,200 particles per cubic meter. The higher the class number, the more are the particles present.

\begin{tabular}{|l|l|l|l|l|l|}
\hline $\begin{array}{l}\text { CLEAN } \\
\text { ROOM } \\
\text { CLASS }\end{array}$ & \multicolumn{5}{l}{$\begin{array}{l}\text { CLASS LIMITS “NOT TO EXCEED” PARTICLES PER CU FT FOR PARTICALS } \\
\text { SIZES SHOWN }\end{array}$} \\
\hline 1 & $0.1 \propto \mathrm{m}$ & $0.2 \times \mathrm{m}$ & $0.3 \times \mathrm{m}$ & $0.5 \propto \mathrm{m}$ & $5 \times \mathrm{m}$ \\
\hline 10 & 35 & 7.5 & 3 & 1 & - \\
\hline 100 & 350 & 75 & 30 & 10 & - \\
\hline 1000 & - & 750 & 300 & 100 & - \\
\hline 10000 & - & - & - & 1000 & 7 \\
\hline 100000 & - & - & - & 10000 & 70 \\
\hline 1000000 & - & - & - & 100000 & 700 \\
\hline
\end{tabular}

\begin{tabular}{|l|l|}
\hline Federal standard 209E & ISO \\
\hline 1 & 3 \\
\hline 10 & 4 \\
\hline 100 & 5 \\
\hline 1000 & 6 \\
\hline 10000 & 7 \\
\hline 100000 & 8 \\
\hline
\end{tabular}

2.2 Sources Of Contamination: The source of the contamination is categorized as external sources and internal sources 
A. External Sources - For any given space, there exists the external influence of gross atmospheric contamination. External contamination is brought in primarily through the air conditioning system through makeup air. Also, external contamination can infiltrate through building doors, windows, cracks, and wall penetrations for pipes, cables and ducts. The external contamination is controlled primarily by

1. High efficiency filtration,

2. Space pressurization and

3. Sealing of space penetrations

B.Internal Sources- The potentially largest source is from people in the clean room, plus shedding of surfaces, process equipment and the process itself. People in the workspace generate particles in the form of skin flakes, lint, cosmetics, and respiratory emissions. Industry generates particles from combustion processes, chemical vapors, soldering fumes, and cleaning agents. Other sources of internal contamination are generatedthrough the activity in combustion, chemical, and manufacturing processes. The size of these particles ranges from 0.001 to several hundred microns. Particles larger than 5 microns tend to settle quickly unless air blown. The greatest concern is that the actual particle deposits on the product. Control is primarily through airflow design. Although airflow design is critical, it alone does not guarantee that clean room conditions will be met. Construction finishes; personnel and garments; materials and equipments are sources of particulate contamination that must be controlled. Important control precautions include:

1. Walls, floors, ceiling tiles, lighting fixtures, doors, and windows construction materials that must be carefully selected to meet clean room standards.

2. People must wear garments to minimize the release of particles into the space. The type of garments depends on the level of cleanliness required by a process. Smocks, coveralls, gloves, and head and shoe covers are clothing accessories commonly used in clean spaces

3. Materials and equipment must be cleaned before entering the clean room.

4. Room entrances such as air locks and pass-through are used to maintain pressure differentials and reduce contaminants.

5. Air showers are used to remove contaminants from personnel before entering the clean space.

\subsection{Controlling Cantaminatian With A Clean Room:}

Clean room contamination is controlled by six major means:

(1) Facility design

(2) Equipment used in the room

(3) Procedures employed

(4) Personnel activity

(5) Environment control

(6) Maintenance

\subsection{Panels:}

ASTM standards are followed strictly in the making of our pre-painted, galvanized steel panels. There is special gasket for air tightness between the frame and fixed panels. Hot dip galvanized steel is used for making inner panel for double skin panels. To achieve uniformity, access doors are made with similar material.

\section{Hvac Facility}

HVAC design for health care facilities is all about providing a safer environment for patients and staff. The basic difference between air conditioning for healthcare facility and that of other building types stem from:

1. The need to restrict air movement in and between the various departments (no cross movement).

2. The specific requirements for ventilation and filtration to dilute and reduce contamination in the form of odor, airborne micro organisms and viruses, and hazardous chemical and radioactive substances. Ventilation effectiveness is very important to maintain appropriate indoor air quality.

3. The different temperature and humidity requirements for various areas and the accurate control of environmental conditions.

4. The design sophistication to minimize the risk of transmission of airborne pathogens and preserve a sterile and healing environment for patients and staff.

These requirements demand very high quantities of outside air along with significant treatment of this ventilation air, including cooling, dehumidifying, reheating, humidifying and filtration. 


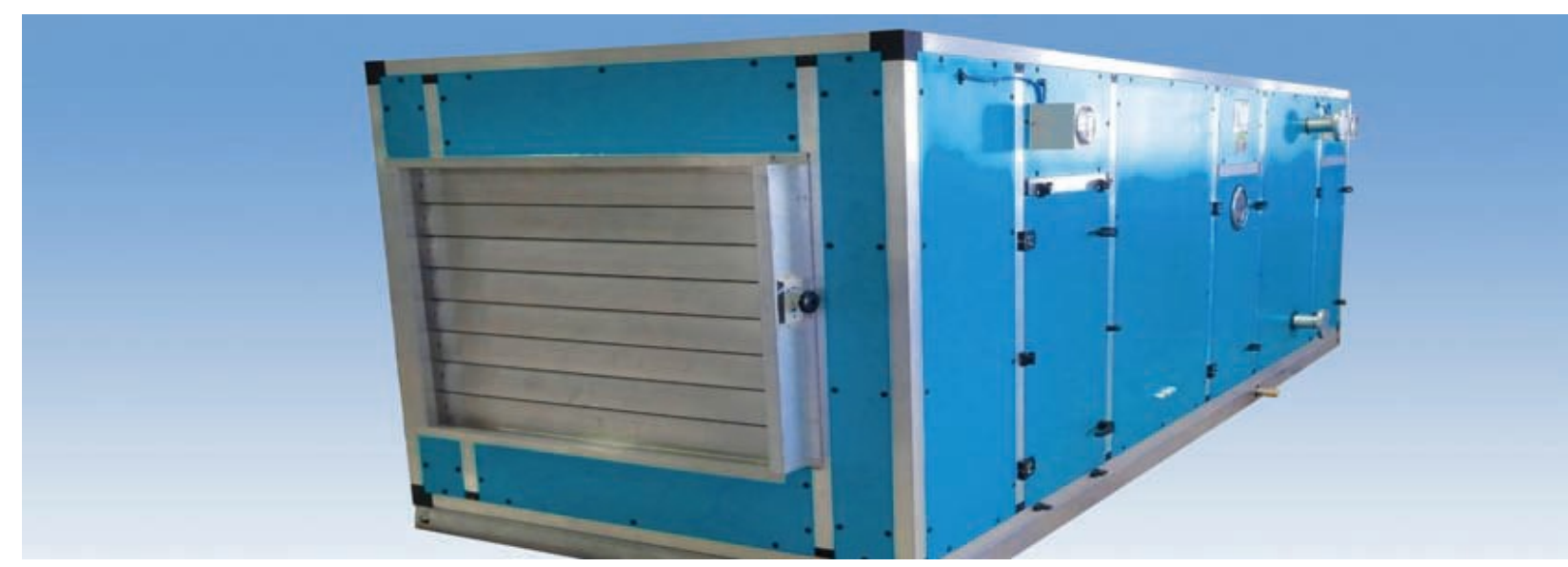

\subsection{Infection Control}

In a hospital environment, there tend to be high concentrations of harmful micro-organisms. From an infection control perspective, the primary objective of hospital design is to place the patient at no risk for infection while hospitalized. The special technical demands include hygiene, reliability, safety and energyrelated issues.

Infections, which may result from activities and procedures taking place within the facility, are a cause for great concern. Three main routes responsible for infections are contact, droplet, and airborne transmission, which are quite affected by room design and construction factors.

\subsection{Contact Transmission}

Contact transmission is the most important and frequent mode of transmission of infections (nosocomial). It can be subdivided into direct-contact transmission and indirect-contact transmission.

a) Direct-contact transmission involves direct body to body contact for the transfer of micro-organisms from an infected person to a susceptible host.

b) Indirect-contact transmission involves the contamination of an inanimate object (such as instruments or dressings) by an infected person.

\subsection{COOLING OR HEATING COILS:}

Standard cooling and heating coils are made in galvanized steel frame with seamless copper tubes with aluminum fins .Ms headers with threaded connection and copper return bends. They are arranged in a staggered form in the direction of air flow .copper tubes are mechanically expanded into continuous corrugated aluminum fins. coils are assembled in slide- in guides for easy removal for maintenance or replacement. for water coils ,air vents and drain plugs are the standard ones. Moisture eliminator can also be provided for the coils, according to air velocities and conditions. Insulated drain pan and drain connections are provided for the cooling coil section

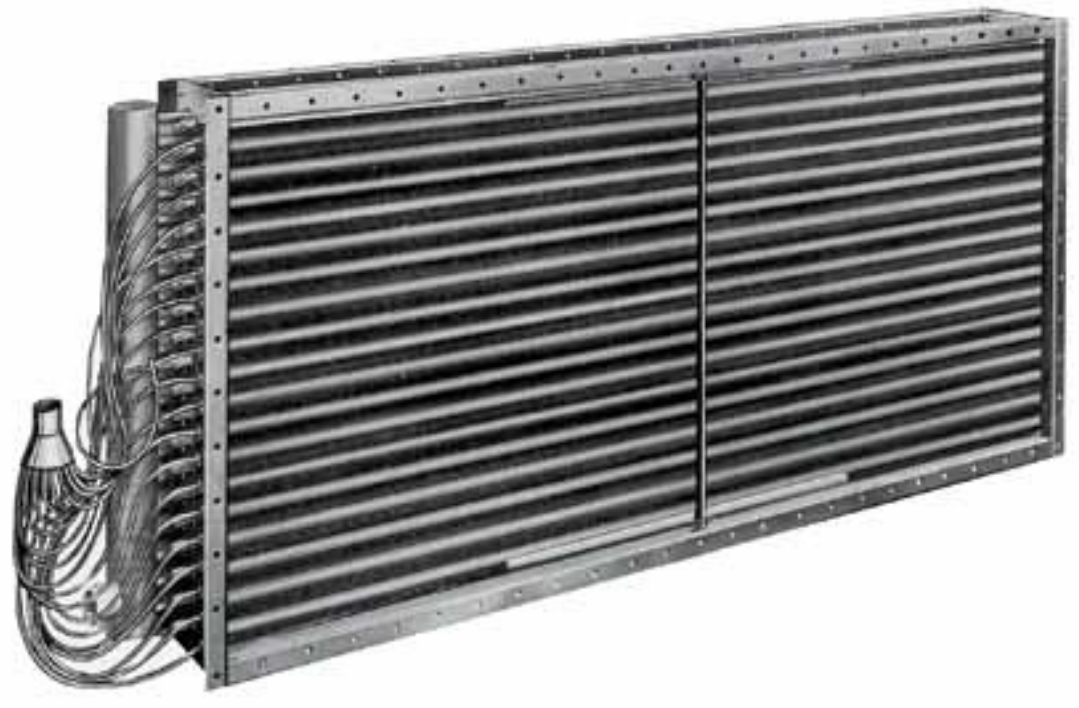




\subsection{FILTRATION (HEPA and ULPA Air Filters):}

Filtration is an important aspect of clean rooms. Most filters are defined by their particle removal efficiency and airflow rate. Clean rooms require very high efficiency filters and for class 100 and below, 100\% HEPA filter coverage is recommended. HEPA (High efficiency particulate arrestance) filtration is $40 \%$ more efficient than the highest efficiency rated ASHRAE filter. Clean room air filtration technology centers around two types:
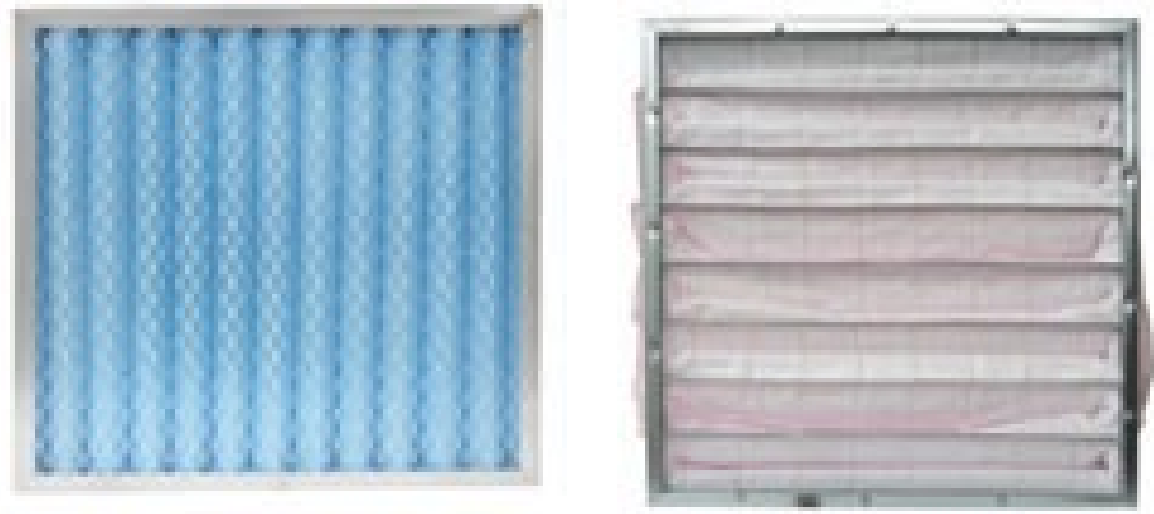

HIGH EFFICIENCY PARTICULATE AIR (HEPA):

HEPA filters are replaceable extended-media dry-type having a minimum particle collective efficiency of 99.97 to $99.997 \%$ for a 0.3 micron particle, and a maximum clean filter pressure drop of $2.54 \mathrm{~cm}(1 ")$ water gauge when tested at rated air flow capacity. 0.3 micron is $1 / 75,000$ of an inch or $1 / 300$, the diameter of the human hair.

\section{ULTRA LOW PENETRATION AIR (ULPA):}

Most ULPA filters are replaceable extended media dry filters that have a minimum particle collection efficiency of $99.9997 \%$ efficient for particles greater than or equal to0.12-micron in size. The high efficiency filters belong to the 'interception'_family of filters and are referred to as 'absolute' super interceptor. Absolute filters are used only where an extremely high level of cleanliness or purity is required. Both HEPA \& ULPA types fall in this category.

\subsection{AIRFLOW DISTRIBUTION AND CONTROL}

Depending on the degree of cleanliness required, it is common for air systems to deliver considerably more air than would be needed solely to meet temperature and humidity design. Airborne particles can be organic or inorganic. Most contamination control problems concern the total contamination within the air.Particles of different sizes behave differently as air moves through a room. Selection of the airflow patterns is a major step in clean room design. Because airflow is such an important aspect of particle control, the design of a clean room requires careful consideration of air motion and airflow patterns. The general air patterns are:

Unidirectional: (sometimes referred as laminar flow) is an airflow pattern in which essentially the entire body of air within a confined area moves with uniform velocity and in single direction with generally parallel airstreams. Clean rooms; class 100 and below have unidirectional airflow pattern.

Non-unidirectional airflow is not unidirectional by having a varying velocity, multiple pass circulation or nonparallel flow direction. Conventional flow clean rooms (class 1000 \&10000) have non-unidirectional or mixed air flow patterns.

Mixed patterns: combine some of each flow type. 


\section{Load estimation:}

\section{Equations}

1. Solar transmission through wall:

$\mathrm{Q}=\mathrm{A} * \mathrm{U} * \mathrm{EqTD}$

Where $A=$ area of the wall $\left(\mathrm{ft}^{2}\right), \mathrm{U}=$ Transmission coefficient $\left(\mathrm{Btu} / \mathrm{hr} / \mathrm{ft}^{2} /{ }^{\circ} \mathrm{f}\right)$

$\mathrm{EqTD}=$ corrected equivalent temperature Difference

2. Transmission gain through partitions, ceiling, floor, glass:

$\mathrm{Q}=\mathrm{A} * \mathrm{U} * \mathrm{TD}$

$\mathrm{TD}=$ Temperature Difference from the surrounding and air conditioning space in ${ }^{\circ} \mathrm{f}$

Where $\mathrm{A}=$ area of the partitions, celling, floor, glass $\left(\mathrm{ft}^{2}\right), \mathrm{U}=$ Transmission coefficient $\left(\mathrm{Btu} / \mathrm{hr} / \mathrm{ft}^{2} /{ }^{\circ} \mathrm{f}\right)$

3. Ventilation load:

$\mathrm{Q}=\mathrm{cfm} *$ temp diff* 1.08

4. People load:

$\mathrm{Q}=$ no of people* sensible heat factor

5. Lighting load:

$\mathrm{Q}=$ area of the room*1.25*3.4

6. Equipment load:

$\mathrm{Q}=$ electrical load*3.4

7. AHU motor load;

$\mathrm{Q}=$ motor electric load $* 3.4$

Subtotal of the Sensible heat $=$ solar transmissions through wall + transmissions through partitions, ceiling, floor, glass + . Ventilation load + People load + Lighting load + Equipment load + AHU motor load

Safety load $=5 \%$ of the subtotal sensible heat load

Total sensible heat load $=$ subtotal of the sensible heat + safety load

Latent heat :

1. ventilation load:

$\mathrm{Q}=\mathbf{c f m}$ *specific humidity diff * bypass factor*0.67

\section{People load:}

$\mathrm{Q}=$ no of people * latent heat factor

Subtotal of latent heat $=$ ventilation load + people load

Safety load $=5 \%$ of the sub total latent heat load

Total latent load $=$ subtotal of latent load + safety load

Tota L Space Heat $=$ Total sensible load + Total latent load

Sensible heat ratio $=$ Total sensible heat $/$ total space heat

Reheat $=(((\text { sensible heat ratio } * \text { total space heat })-\text { total sensible heat }) /(1 \text {-sensible heat factor }))^{*} 0.293 / 1000$

Dehumidified $\mathrm{cfm}=(($ total sensible heat + reheat $) /($ room dry bulb temp - apparatus dew point $) *(1-b f) * 1.08)$

Return air quantity $=$ Selected supply air quantity + infiltration air - ex-filtration- exhaust air

Bleed off Air Qty = Fresher air qty + return air qty-selected supply air qty 


\section{Load Calculation Results}

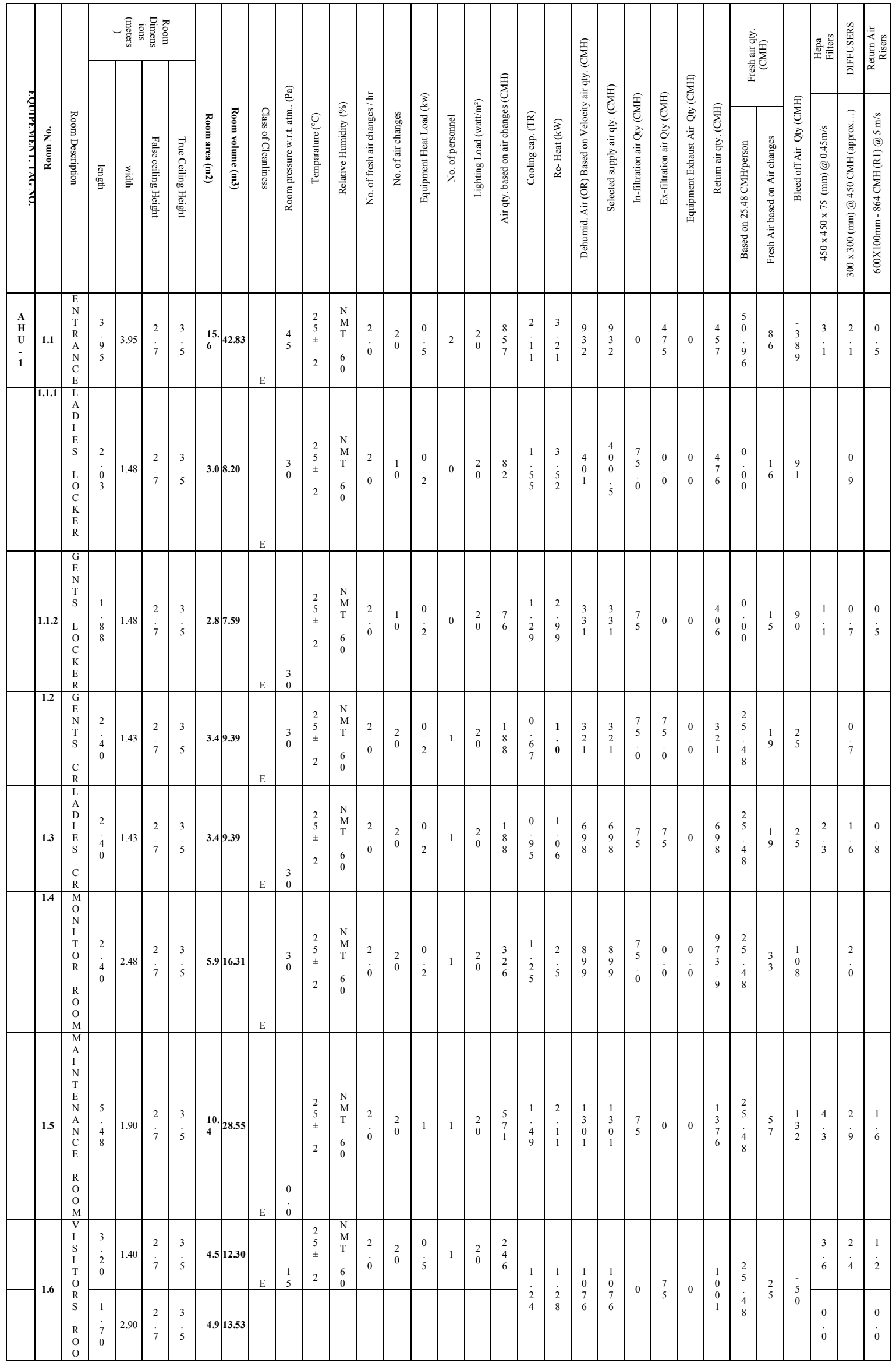


Design, Installation And Commissioning Of Clean Room And Hvac Facility For Stem Cell

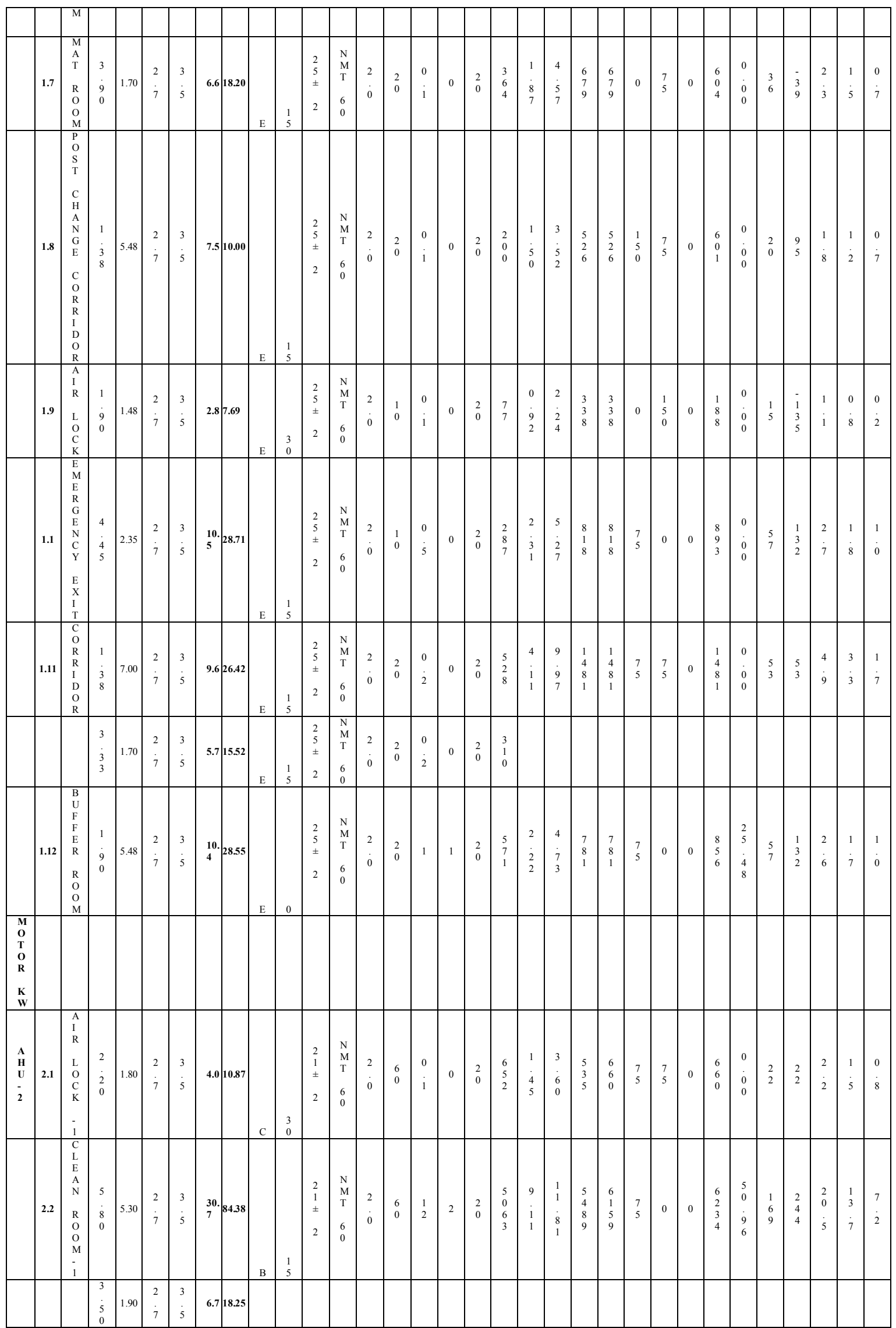




\begin{tabular}{|c|c|c|c|c|c|c|c|c|c|c|c|c|c|c|c|c|c|c|c|c|c|c|c|c|c|c|c|c|c|c|c|}
\hline $\begin{array}{l}\mathbf{A} \\
\mathbf{H} \\
\mathbf{U}- \\
\mathbf{8}\end{array}$ & $\begin{array}{l}8 \\
i\end{array}$ & \begin{tabular}{|l}
$\mathrm{C}$ \\
$\mathrm{L}$ \\
$\mathrm{E}$ \\
$\mathrm{A}$ \\
$\mathrm{N}$ \\
$\mathrm{R}$ \\
$\mathrm{O}$ \\
$\mathrm{O}$ \\
$\mathrm{M}$
\end{tabular} & \begin{tabular}{|l|}
3. \\
8 \\
9
\end{tabular} & $\begin{array}{l}3 \\
9 \\
9 \\
3\end{array}$ & $\begin{array}{l}2 \\
7 \\
4 \\
5\end{array}$ & $\begin{array}{l}3 \\
5\end{array}$ & $\begin{array}{l}1 \\
5 \\
3\end{array}$ & $\begin{array}{l}4 \\
1 \\
9 \\
1\end{array}$ & C & $c \mid \begin{array}{l}3 \\
0\end{array}$ & $\begin{array}{l}2 \\
4 \\
\pm \\
2\end{array}$ & $\begin{array}{l}\mathrm{N} \\
\mathrm{M} \\
\mathrm{T} \\
6 \\
0\end{array}$ & 2 & $\begin{array}{l}3 \\
0\end{array}$ & 2 & 2 & $\begin{array}{l}2 \\
0\end{array}$ & $\begin{array}{l}1 \\
2 \\
5 \\
7\end{array}$ & \begin{tabular}{|l|}
2 \\
5 \\
9 \\
9
\end{tabular} & \begin{tabular}{|l|}
3 \\
4 \\
8 \\
\end{tabular} & \begin{tabular}{l|}
1 \\
7 \\
4 \\
3 \\
\end{tabular} & $\begin{array}{l}1 \\
7 \\
4 \\
3 \\
4 \\
4 \\
8\end{array}$ & 0 & $\begin{array}{l}7 \\
5\end{array}$ & 0 & \begin{tabular}{l|l}
1 & 5 \\
6 & 0 \\
6 & 9 \\
8 & 6
\end{tabular} & & \begin{tabular}{l|l}
8 & 9 \\
4 & 9 \\
&
\end{tabular} & \begin{tabular}{l|l}
9 & 5 \\
9 & 8
\end{tabular} & $\begin{array}{l}3 \\
9\end{array}$ & $\begin{array}{l}1 \\
9\end{array}$ \\
\hline & $\begin{array}{l}8 \\
2\end{array}$ & \begin{tabular}{|l}
$\mathrm{N}$ \\
$\mathrm{U}$ \\
$\mathrm{R}$ \\
$\mathrm{S}$ \\
$\mathrm{E}$ \\
$\mathrm{O}$ \\
$\mathrm{O}$ \\
$\mathrm{S}$ \\
$\mathrm{S}$ \\
$\mathrm{C}$ \\
$\mathrm{R}$ \\
$\mathrm{V}$ \\
$\mathrm{A}$ \\
$\mathrm{T}$ \\
$\mathrm{I}$ \\
$\mathrm{O}$ \\
$\mathrm{N}$ \\
\end{tabular} & \begin{tabular}{|l|}
3. \\
8 \\
9
\end{tabular} & $\begin{array}{l}2 \\
6 \\
0\end{array}$ & $\begin{array}{l}2 \\
7 \\
4 \\
5\end{array}$ & $\begin{array}{l}3 \\
5\end{array}$ & $\begin{array}{l}1 \\
0 \\
1\end{array}$ & $\begin{array}{l}2 \\
7 \\
7 \\
3\end{array}$ & 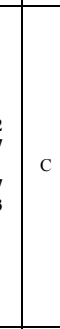 & $\begin{array}{l}1 \\
5\end{array}$ & $\begin{array}{l}2 \\
4 \\
\pm \\
2\end{array}$ & $\begin{array}{l}\mathrm{N} \\
\mathrm{M} \\
\mathrm{T} \\
6 \\
0\end{array}$ & 2 & $\begin{array}{l}3 \\
0\end{array}$ & 1 & 1 & $\begin{array}{l}2 \\
0\end{array}$ & $\begin{array}{l}8 \\
3 \\
2\end{array}$ & $\begin{array}{l}1 \\
4 \\
3\end{array}$ & $\begin{array}{l}1 \\
9 \\
2 \\
2\end{array}$ & \begin{tabular}{|l|}
8 \\
9 \\
4
\end{tabular} & $\begin{array}{l}8 \\
9 \\
3 \\
9 \\
9 \\
6\end{array}$ & $\begin{array}{l}7 \\
5\end{array}$ & 0 & 0 & \begin{tabular}{l|l}
2 & 2 \\
9 & 5 \\
6 & 4 \\
9 & 4
\end{tabular} & & & & $\begin{array}{l}2 \\
0 \\
0\end{array}$ & $\begin{array}{l}1 \\
i\end{array}$ \\
\hline & $\begin{array}{l}8 \\
\dot{3}\end{array}$ & \begin{tabular}{|l}
$\mathrm{W}$ \\
$\mathrm{A}$ \\
$\mathrm{S}$ \\
$\mathrm{H}$ \\
$\mathrm{A}$ \\
$\mathrm{R}$ \\
$\mathrm{E}$ \\
$\mathrm{A}$
\end{tabular} & \begin{tabular}{|l|}
1. \\
8 \\
9 \\
\end{tabular} & $\begin{array}{l}3 \\
4 \\
9\end{array}$ & $\begin{array}{l}2 \\
7\end{array}$ & $\begin{array}{l}3 \\
5\end{array}$ & $\begin{array}{l}6 \\
6\end{array}$ & $\begin{array}{l}9 \\
6\end{array}$ & C & $\begin{array}{l}1 \\
5\end{array}$ & $\begin{array}{l}2 \\
4 \\
\pm \\
2\end{array}$ & $\begin{array}{l}\mathrm{N} \\
\mathrm{M} \\
\mathrm{T} \\
6 \\
0\end{array}$ & 2 & $\begin{array}{l}3 \\
0\end{array}$ & $\begin{array}{l}0 . \\
2\end{array}$ & 0 & $\begin{array}{l}2 \\
0\end{array}$ & $\begin{array}{l}2 \\
8 \\
7\end{array}$ & $\begin{array}{l}1 \\
7 \\
8\end{array}$ & \begin{tabular}{|l|}
4 \\
3 \\
1 \\
1
\end{tabular} & $\begin{array}{l}6 \\
4 \\
2 \\
\end{array}$ & $\begin{array}{l}6 \\
4 \\
1 \\
\dot{8} \\
1\end{array}$ & 0 & 0 & 0 & \begin{tabular}{l|l}
6 & 0 \\
4 & 0 \\
2 & 0
\end{tabular} & \begin{tabular}{l|l}
0 & \\
0 & 1 \\
0 & 9
\end{tabular} & \begin{tabular}{l|l}
1 & 1 \\
9 & 9
\end{tabular} & $\begin{array}{ll}1 & 2 \\
9 & 1\end{array}$ & $\begin{array}{l}1 \\
4\end{array}$ & $\begin{array}{l}0 \\
7\end{array}$ \\
\hline
\end{tabular}

\begin{tabular}{|l|}
\hline M \\
\hline O \\
T \\
O \\
R \\
K \\
W \\
\hline
\end{tabular}

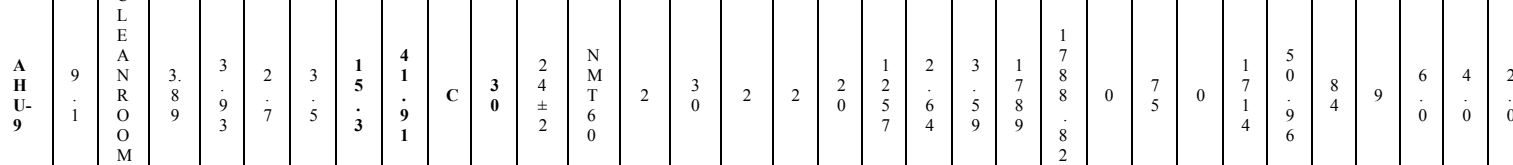

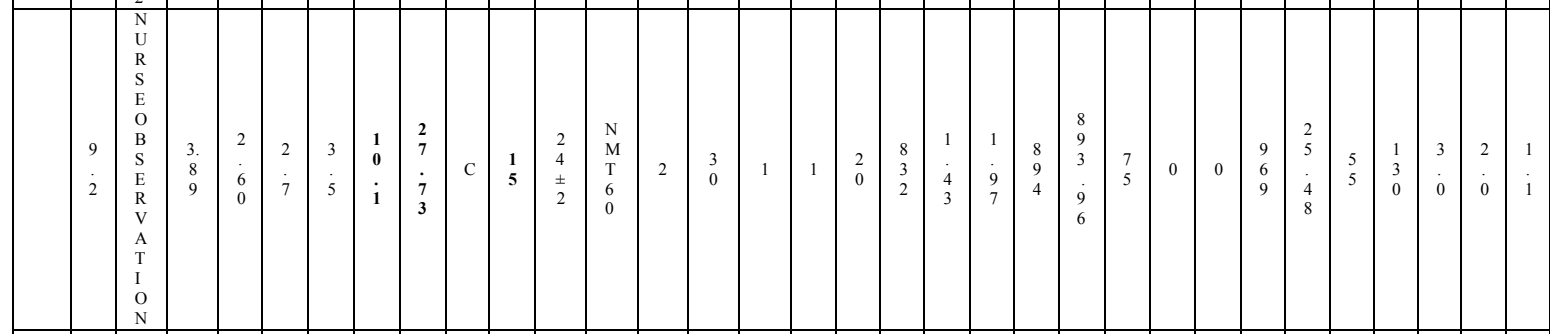

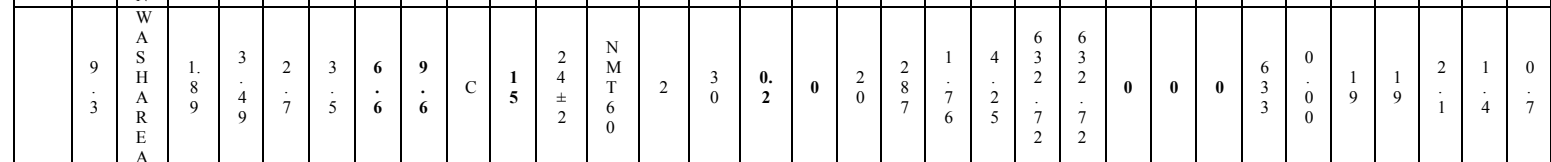

\begin{tabular}{|c|}
\hline $\mathbf{M}$ \\
\hline $\mathbf{O}$ \\
$\mathrm{T}$ \\
$\mathrm{O}$ \\
$\mathrm{R}$ \\
$\mathrm{R}$ \\
$\mathrm{K}$ \\
$\mathbf{W}$ \\
\hline
\end{tabular}

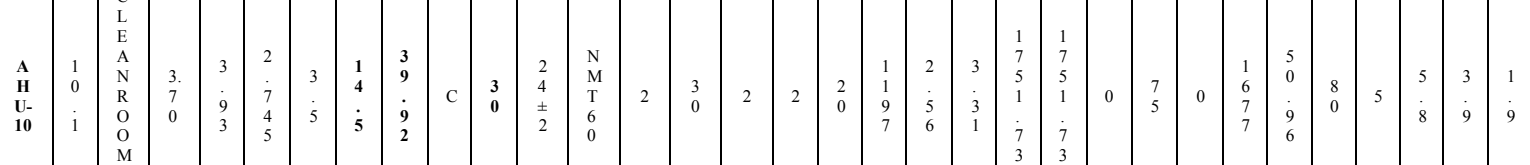

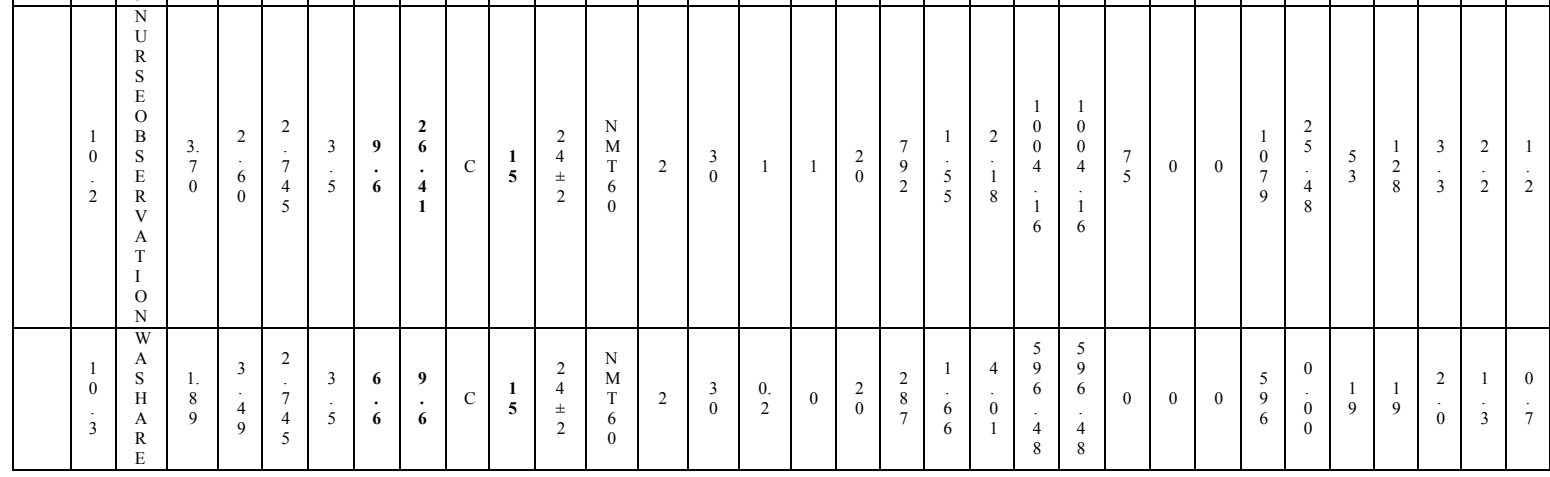




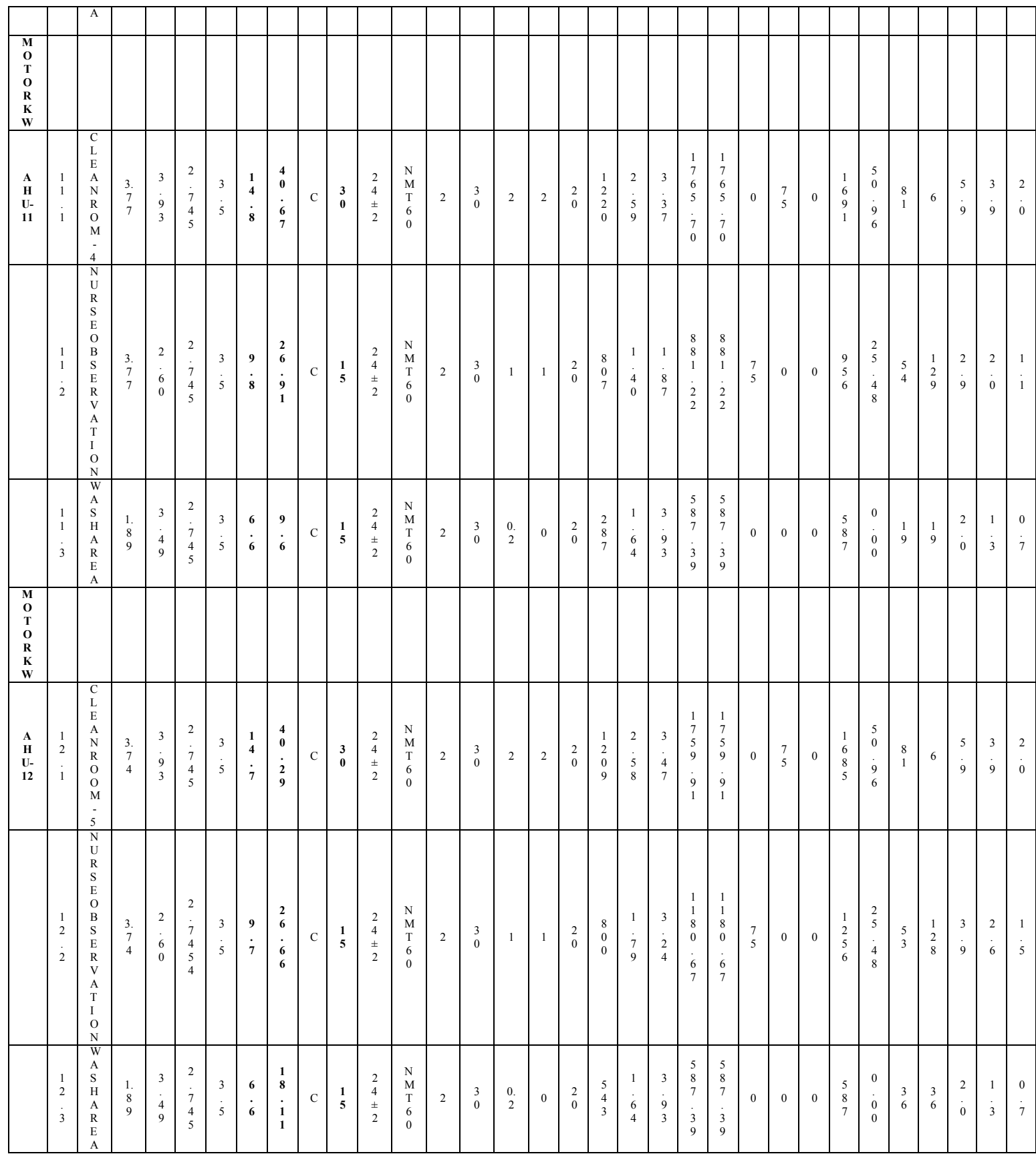

\begin{tabular}{|c|c|c|c|c|c|c|c|c|c|c|c|c|c|c|c|c|c|c|c|c|c|c|c|c|c|c|c|c|c|c|c|c|}
\hline $\begin{array}{l}\mathbf{A} \\
\mathbf{H} \\
\mathbf{U}-\end{array}$ & $\begin{array}{l}1 \\
3 \\
i\end{array}$ & \begin{tabular}{|l|l}
$\mathrm{C}$ \\
$\mathrm{L}$ \\
$\mathrm{E}$ \\
$\mathrm{A}$ \\
$\mathrm{N}$ \\
$\mathrm{R}$ \\
$\mathrm{O}$ \\
$\mathrm{O}$ \\
$\mathrm{M}$ \\
$\mathrm{M}$ \\
\\
\end{tabular} & $\begin{array}{l}3 . \\
8 \\
9\end{array}$ & $\begin{array}{l}3 \\
9 \\
9 \\
3\end{array}$ & $\begin{array}{l}2 \\
7 \\
4 \\
5\end{array}$ & $\begin{array}{l}3 \\
5\end{array}$ & $\begin{array}{l}1 \\
5 \\
3\end{array}$ & \begin{tabular}{|l}
4 \\
1 \\
9 \\
1 \\
1
\end{tabular} & C & $\begin{array}{l}3 \\
0\end{array}$ & $\begin{array}{l}2 \\
4 \\
\pm \\
2\end{array}$ & \begin{tabular}{|l}
$\mathrm{N}$ \\
$\mathrm{M}$ \\
$\mathrm{T}$ \\
6 \\
0
\end{tabular} & 2 & $\begin{array}{l}3 \\
0 \\
0\end{array}$ & 2 & 2 & $\begin{array}{l}2 \\
0\end{array}$ & $\begin{array}{l}1 \\
2 \\
5 \\
7\end{array}$ & $\begin{array}{l}2 \\
6 \\
4 \\
\end{array}$ & \begin{tabular}{l|}
1 \\
2 \\
0
\end{tabular} & $\begin{array}{l}1 \\
7 \\
8 \\
8 \\
8 \\
2 \\
2\end{array}$ & $\begin{array}{l}1 \\
7 \\
8 \\
8 \\
.8 \\
8 \\
2\end{array}$ & 0 & $\begin{array}{l}7 \\
5\end{array}$ & 0 & $\begin{array}{l}1 \\
7 \\
1 \\
4\end{array}$ & $\begin{array}{l}5 \\
0 \\
9 \\
6\end{array}$ & $\begin{array}{l}8 \\
4\end{array}$ & 9 & $\begin{array}{l}6 \\
0\end{array}$ & $\begin{array}{l}4 \\
0\end{array}$ & $\begin{array}{l}2 \\
\dot{0}\end{array}$ \\
\hline & $\begin{array}{l}1 \\
3 \\
2\end{array}$ & \begin{tabular}{|l}
$\mathrm{N}$ \\
$\mathrm{U}$ \\
$\mathrm{R}$ \\
$\mathrm{S}$ \\
$\mathrm{S}$ \\
$\mathrm{E}$ \\
$\mathrm{O}$ \\
$\mathrm{B}$ \\
$\mathrm{S}$ \\
$\mathrm{E}$ \\
$\mathrm{R}$ \\
$\mathrm{R}$ \\
$\mathrm{V}$ \\
$\mathrm{A}$ \\
$\mathrm{T}$ \\
$\mathrm{I}$ \\
$\mathrm{O}$ \\
$\mathrm{N}$
\end{tabular} & $\begin{array}{l}3 . \\
7 \\
4\end{array}$ & $\begin{array}{l}2 \\
6 \\
6 \\
0\end{array}$ & $\begin{array}{l}2 \\
7 \\
4 \\
5\end{array}$ & $\begin{array}{l}3 \\
5 \\
5\end{array}$ & $\begin{array}{l}9 \\
7\end{array}$ & \begin{tabular}{|l}
2 \\
6 \\
6 \\
6 \\
6
\end{tabular} & $\mathrm{c}$ & $\begin{array}{l}1 \\
5\end{array}$ & $\begin{array}{l}2 \\
4 \\
\pm \\
2\end{array}$ & \begin{tabular}{|l}
$\mathrm{N}$ \\
$\mathrm{M}$ \\
$\mathrm{T}$ \\
6 \\
0
\end{tabular} & 2 & $\begin{array}{l}3 \\
0\end{array}$ & 1 & 1 & $\begin{array}{l}2 \\
0\end{array}$ & $\begin{array}{l}8 \\
0 \\
0\end{array}$ & $\begin{array}{l}1 \\
7 \\
9\end{array}$ & $\begin{array}{l}3 \\
2 \\
2\end{array}$ & $\begin{array}{l}1 \\
1 \\
7 \\
8 \\
8 \\
9 \\
9\end{array}$ & $\begin{array}{l}1 \\
1 \\
7 \\
8 \\
8 \\
8 \\
9\end{array}$ & $\begin{array}{l}7 \\
5\end{array}$ & 0 & 0 & $\begin{array}{l}1 \\
2 \\
5 \\
4\end{array}$ & $\begin{array}{l}2 \\
5 \\
4 \\
8\end{array}$ & $\begin{array}{l}5 \\
3\end{array}$ & $\begin{array}{l}1 \\
2 \\
8\end{array}$ & $\begin{array}{l}3 \\
9\end{array}$ & $\begin{array}{l}2 \\
6\end{array}$ & $\begin{array}{l}1 \\
5 \\
5\end{array}$ \\
\hline & $\begin{array}{l}1 \\
3 \\
3 \\
\end{array}$ & \begin{tabular}{|l} 
W \\
A \\
S \\
H \\
\end{tabular} & \begin{tabular}{|l}
1. \\
8 \\
9 \\
\end{tabular} & $\begin{array}{l}3 \\
4 \\
9 \\
\end{array}$ & \begin{tabular}{|l}
2 \\
7 \\
4 \\
\end{tabular} & $\begin{array}{l}3 \\
5 \\
\end{array}$ & $\begin{array}{l}6 \\
6 \\
\end{array}$ & \begin{tabular}{|l}
1 \\
8 \\
$\mathrm{i}$ \\
\end{tabular} & $\mathrm{C}$ & $\begin{array}{l}1 \\
5\end{array}$ & $\begin{array}{l}2 \\
4 \\
\pm \\
2\end{array}$ & $\begin{array}{l}\mathrm{N} \\
\mathrm{M} \\
\mathrm{T} \\
6\end{array}$ & 2 & $\begin{array}{l}3 \\
0\end{array}$ & $\frac{0 .}{2}$ & 0 & $\begin{array}{l}2 \\
0\end{array}$ & $\begin{array}{l}5 \\
4 \\
3 \\
\end{array}$ & \begin{tabular}{l|} 
\\
7 \\
3 \\
\end{tabular} & \begin{tabular}{|l|}
4 \\
$\mathrm{i}$ \\
9
\end{tabular} & $\begin{array}{l}6 \\
2 \\
3 \\
\end{array}$ & $\begin{array}{l}6 \\
2 \\
3\end{array}$ & 0 & 0 & 0 & $\begin{array}{l}6 \\
2 \\
4 \\
\end{array}$ & \begin{tabular}{l|l}
0 \\
0 \\
0 \\
0
\end{tabular} & $\begin{array}{l}3 \\
6\end{array}$ & $\begin{array}{l}3 \\
6\end{array}$ & $\begin{array}{l}2 \\
i\end{array}$ & \begin{tabular}{l|l}
1 \\
4 \\
\end{tabular} & 0 \\
\hline
\end{tabular}




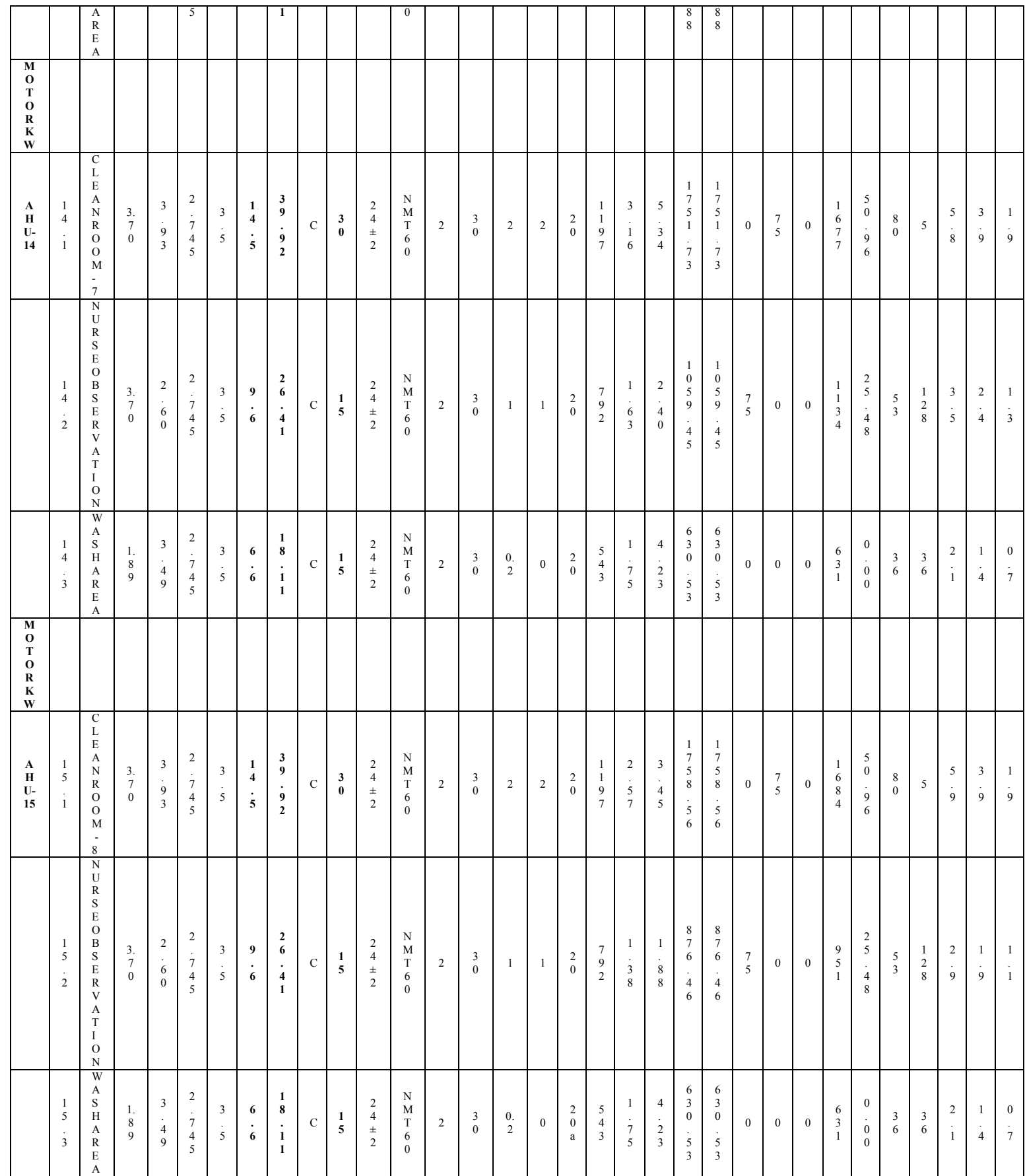

\section{Conclusion}

Now a days, many manufacturing process requires that space to be designed to control particulate and microbial contamination while maintaining clean room facility with installation and operating cost. Present days we are using filters and panels in addition for constructed building In this thesis, the system design thermal loads, filtration level and cleanness, pressures produced in the constructing building by vary with the normal brick wall, brick wall with attached panels are calculated. By observing the design of thermal loads in normalbrick wall with panels is better than normal wall, because its heat transfer rate of normal wall is more. In this thesis filtration level is good by using brick wall with panels ,because there is no dust particles form on the wall with panel. In the design analysis the cooling load tonnage value of brick wall with panel is 97TR and normal brick wall is 140TR. So that the cooling load and air flow is very good by using brick wall with panel. Design of this system is used in NIMS hospital in Hyderabad. 


\subsection{Future Scope}

From this thesis, we have concluded that using filter materials will be varying number of filters will be reduced in the room and also air handling unit size will be decrease.

\section{References}

[1] A. Bhatia," A BASIC DESIGN GUIDE FOR CLEAN ROOM APPLICATIONS".

[2] Roy J.Dossat,"PRINCIPLES OF REFRIGERATION SECOND EDITION".

[3] Shan K. Wang," HAND BOOOK OF AIR CONDITIONING AND REFRIGERATION".

[4] National Experts Organization, "STUDY MATERIAL ON EFFICIENT OPERATION AND MAINTENANCE OF A.C AND REFRIGERATION EQIPMENT",

[5] Carrier air conditioning, "HAND BOOK OF AIR CONDITIONING SYSTEM DESIGN",

[6] OPERATION AND MAINTANENCE MANNUAL OF STAGE-1 A.C AND VENTILATION SYSTEM".

[7] OPERATION AND MAINTANENCE MANNUAL OF STAG-2 A.C AND VENTILATION SYSTEM".

[8] S.C.Arora and S.Domakundwar,"REFRIGERATION AND AIR CONDITIONING".

[9] R.S.Kurmi and J.K.GUPTHA,"REFRIGERATION AND AIR CONDITIONING". 